\title{
EFFECT OF COCONUT SHELL ASH ON PORE WATER PRESSURE CHANGES IN SAND
}

\author{
*Gabriel Jose G. Lim¹, Mary Ann Q. Adajar², and Erica Elice S. Uy² \\ ${ }^{1}$ Graduate Student, De La Salle University, Philippines; ${ }^{2}$ Faculty, De La Salle University, Philippines \\ *Corresponding Author, Received: 06 Oct. 2021, Revised: 01 Dec. 2021, Accepted: 09 Jan. 2022
}

\begin{abstract}
Previous studies showed that the addition of coconut shell ash (CSA) to soil improved the California Bearing Ratio, Maximum Dry Density, and Unconfined Compressive Strength. But the effect of CSA in decreasing soil susceptibility to static liquefaction has yet to be investigated. Static liquefaction is a major concern because it is defined as when soil loses its strength and behaves like a fluid. This causes settlements, damages buildings, and endangers lives. The loss in soil strength is attributed to the increase in pore water pressure. Pore water pressure buildup is more likely to happen in loose and saturated sands. This study hypothesizes that the particle size and the chemical property of CSA can reduce the liquefaction susceptibility of sands by decreasing pore water pressure buildup when the sand is subjected to vertical loads. For the experiment, the consolidated undrained (CU) triaxial test was conducted. The Cam-Clay model was used to analyze soil behavior between the control samples and the samples mixed with CSA. Results show that administering $5 \%$ CSA expanded the soil's yield surface, improving soil's ability to respond elastically to deformations. Five percent CSA decreased pore water pressure buildup in the samples subjected to $50 \mathrm{kPa}$ and $100 \mathrm{kPa}$ consolidating pressures by $6.53 \%$ and $5.55 \%$, respectively. However, for the sample subjected to 25 $\mathrm{kPa}$ consolidating pressure, $5 \%$ CSA caused an adverse effect by increasing pore water pressure buildup by $10.73 \%$. The low consolidating pressure negates the effect of CSA and there should be a sufficiently high consolidating pressure to decrease pore water pressure buildup.
\end{abstract}

Keywords: Coconut Shell Ash, Critical State, Cam-Clay Model, Pore Water Pressure Buildup

\section{INTRODUCTION}

Soil liquefaction is a phenomenon where the strength of soil is decreased by loads. Soils are made up of an assemblage of individual soil particles. The weight of these particles produces contact forces among the particles. Contact forces are responsible for holding the particles together and giving the soil its strength. Liquefaction occurs in saturated soils, which are soils with voids filled with water. During loading, soils break down into a denser configuration. The water in the voids is compressed, and water pressure is generated. Water pressure decreases the contact forces among the soil particles. In severe cases, high water pressures cause the particles to completely lose contact with each other. This causes soil to behave like a liquid [1]-[4]. The current trend in geotechnical engineering is to improve soil using waste materials instead of conventional processes and additives, like fly ash and cement [5]-[16]. Using locally available waste materials will help the environment and reduce construction costs [17]-[28]. Previous experiments concluded that the introduction of additives like slag, Bassanite, fibers, grout, and denitrifying bacteria decreased pore water pressure generation in soils. However, past studies have yet to investigate the effect of coconut shell ash (CSA) in reducing pore water pressure generation [29]-[34]. With a scanning electron microscope, the mean particle size of CSA was 34.3 microns. With its small particle size, CSA can occupy soil voids and reduce the amount of water held by the soil, which can decrease pore water pressure buildup [35]. The effect of CSA as a stabilizer for the base course of pavements has been investigated. Dosages of $5 \%$, $10 \%$, and $15 \%$ CSA were tested, and it was found that $5 \%$ CSA produced the best results [36]. The Philippine Institute of Volcanology and Seismology (PHILVOCS) declared the areas of Malabon, Manila, Pasay, Marikina, Pateros, Pasig, and the coastal area of Muntinlupa to have very high liquefaction susceptibility. Heavy loads from buildings in these areas can trigger pore water pressure buildup [37]. It is the objective of this study to measure and compare the generation of the pore water pressure, under consolidated undrained (CU) triaxial test, among the sand samples at $0 \%$ and $5 \%$ CSA mixtures, at a target relative density. The objective also includes determining shear strength parameters and validating stress-strain responses of modified soil through obtaining an overconsolidation ratio.

\section{RESEARCH SIGNIFICANCE}

Pore water pressure buildup is unwanted as it can lead to liquefaction. Liquefaction is a concern for people who live in liquefaction zones, like coastal areas, places near-earth dams, and places 
with rising water tables. The application of this study extends to roads and pavements. This study benefits engineer, contractors, land and building owners who look for cheaper alternatives to decrease liquefaction susceptibility. The reuse of coconut shell waste addresses the pollution surplus, benefiting the community and the environment.

\section{CAM-CLAY MODEL}

Use at most three levels of headings that correspond to chapters, sections, and subsections. The first level headings for chapter titles should be in 10pt, bold, justified, and upper case font. Leave one blank line before and after the first level headings, respectively. geotechnical engineers because it incorporates volume changes in modeling soil behavior. The Cam-Clay Model states that all soils will fail in a unique failure surface defined by deviatoric stress (q), effective mean stress (p'), and void ratio (e). It is used when sufficient soil tests cannot be conducted or when there is a need to estimate soil responses to changes in loading during and after construction. An example is when a client makes a last-minute change by adding another story to a structure but does not want to finance any further soil testing. The Cam-Clay model is used to determine whether the soil can support an additional story [38]. It is known that the buildup of pore water pressure accelerates after soil yields. With void ratio considered, the Cam-Clay model defines the range of stresses that would result in soil yielding. With this, engineers can determine when to slow down the rate of construction or how to manage heavy machinery on the construction site, to avoid failure caused by excess pore water pressure generation [39]. Other models incorporate critical state concepts, like the Modified Cam-Clay model and the Nor-Sand model. The Cam-Clay model was used because it is simple, consistent, and arguably still the most influential soil model proposed [40]. Many sophisticated critical state models have been proposed but these models still adopt the original Cam-Clay model as their backbone [41].

In this study, the original Cam-Clay model was used for undrained analysis, proving its suitability for this study. The elements of the Cam-Clay model include the yield surface, critical state line in the qp' space, critical state line in the e-ln p' space and normal consolidation line. These are defined by Eq. 1, Eq. 2, Eq. 3, and Eq. 4, respectively. The CamClay model also consists of the total stress path and the effective stress path. The total stress path and the effective stress path are plotted using the data from the consolidated undrained triaxial test.

$$
\frac{q}{M p^{\prime}}+\ln \left(\frac{p^{\prime}}{p_{o}^{\prime}}\right)=0
$$

$$
\begin{aligned}
& q=M p^{\prime} \\
& e=\Gamma+\lambda \ln p^{\prime} \\
& e=N_{p}+\lambda \ln p^{\prime}
\end{aligned}
$$

\section{EXPERIMENTAL PROGRAM}

\subsection{Index Tests}

The index properties of the CSA were obtained by ASTM standards. The following are the tests performed: Specific Gravity Test (ASTM D854), Maximum Void Ratio Test (ASTM D4253), and Minimum Void Ratio Test (ASTM D4254).

\subsection{Consolidated Undrained Triaxial Test}

The consolidated undrained triaxial test was performed based on ASTM D4767 - 02. The sample preparation method used was the air pluviation method. Two percentages of CSA were adopted in this study. Zero percent and five percent CSA were mixed with loose Ottawa sand. For the saturation phase, the cell pressure is kept at a pressure difference of $5 \mathrm{kPa}$ from the backpressure to prevent sample swelling. A full saturation condition is attained when Skempton's B-value is greater than 0.95 , this is defined by Eq. 5 .

$B=\frac{\Delta u}{\Delta \sigma_{3}}>0.95$

For the consolidation phase, the consolidating pressures were set at $25 \mathrm{kPa}, 50 \mathrm{kPa}$, and $100 \mathrm{kPa}$. In this study, the samples are allotted thirty minutes to consolidate. For the shearing phase, the rate of loading for an undrained condition is usually $1 \%$ axial strain, but this did not cause any significant change in pore water pressure. The axial strain was slowly increased to $2 \%$ and $5 \%$, before settling for a $10 \%$ axial strain. Ten percent axial strain caused enough pore water pressure generation required for this study. The strain was applied until the stroke limit was reached.

\section{RESULTS AND DISCUSSION}

\subsection{Index Test}

Summarized in Table 1 are the index properties of CSA. The specific gravity of CSA falls within the range of values found in previous studies [42-43].

\subsection{Strain Curves}

Larger consolidating pressures allow sand to take more stress at the same strain. The samples subjected to the $100 \mathrm{kPa}$ consolidating pressure are denser than the other samples subjected to $25 \mathrm{kPa}$ 
and $50 \mathrm{kPa}$ consolidating pressures. A peak is observed in the samples subjected to $100 \mathrm{k} \mathrm{Pa}$ consolidating pressure because denser soils tend to dilate and exhibit peaks. Critical state was taken at $10 \%$ axial strain. The stress-strain curves for the samples are shown in Fig. 1 and Fig. 2.

Table 1. Index Properties

\begin{tabular}{cc}
\hline Index Property & Value \\
\hline Specific Gravity $\left(\mathrm{G}_{\mathrm{s}}\right)$ & 1.525 \\
Maximum Void Ratio $(\max )$ & 1.778 \\
Minimum Void Ratio $\left(\mathrm{e}_{\min }\right)$ & 0.804 \\
\hline
\end{tabular}

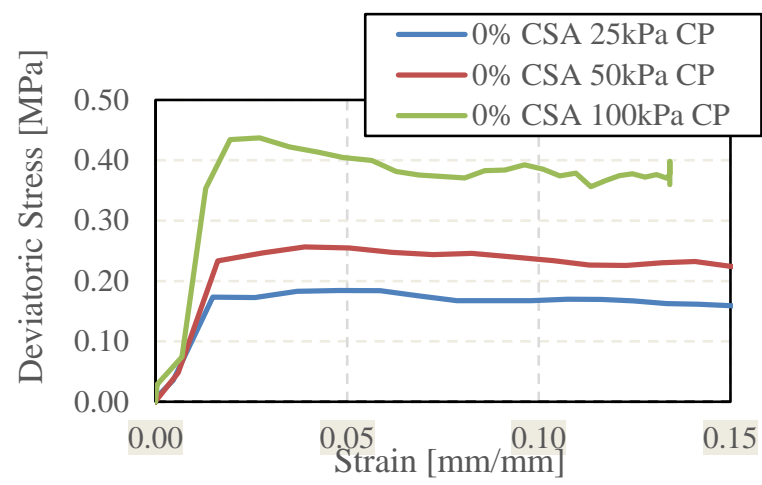

Fig. 1 Stress-Strain Curve for 0\% CSA Group

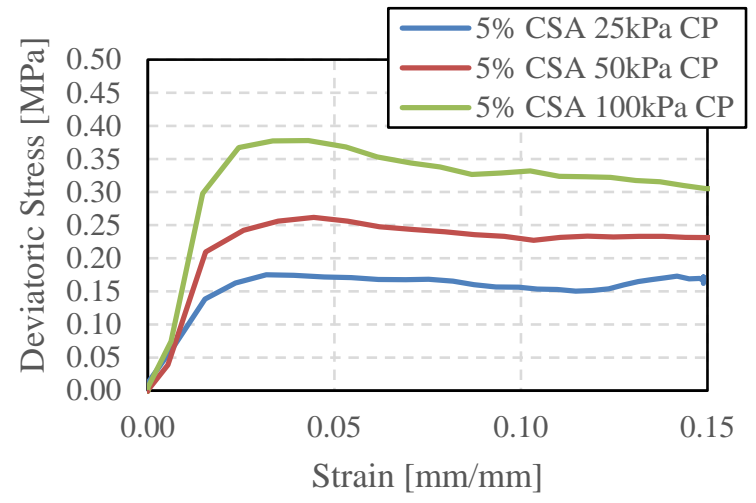

Fig. 2 Stress-Strain Curve for 5\% CSA Group

\subsection{Pore Water Pressure Buildup}

The pore water pressure-strain curves of the samples are shown in Fig. 3 to 5. It is observed that pore water pressure fluctuates much more in samples that were subjected to the $25 \mathrm{kPa}$ consolidating pressure. Samples that were subjected to the $100 \mathrm{kPa}$ consolidating pressure exhibited fewer fluctuations and much flatter curves. Larger consolidating pressures decreased pore water pressure changes. Observing Figure 3, the graph of $0 \%$ CSA resembled a flat line once $5 \%$ axial strain was reached, while the graph of $5 \%$ CSA exhibited relatively more fluctuations. While both samples were subjected to $50 \mathrm{kPa}$ consolidating pressure, the sample mixed with $5 \%$ CSA exhibited a flat stressstrain curve. Five percent CSA was shown to decrease fluctuations, thus resulting in more stable pore water pressure-strain curve behavior. The same is observed from the graphs in Fig. 4 and Fig. 5.

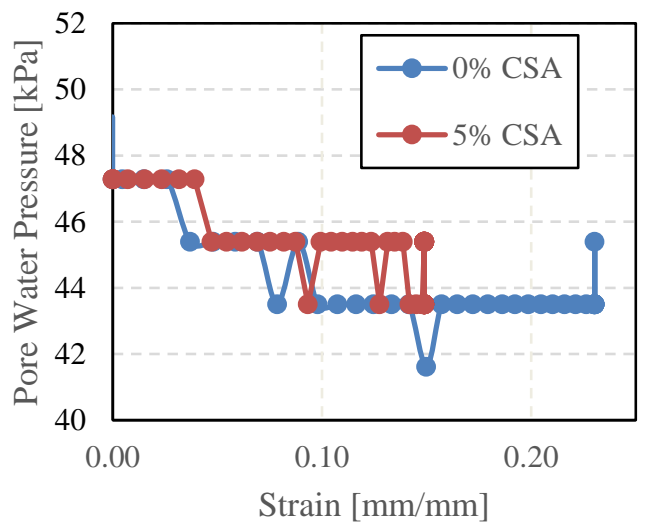

Fig. 3 Pore Water Pressure-Strain Curve at 25kPa Consolidating Pressure

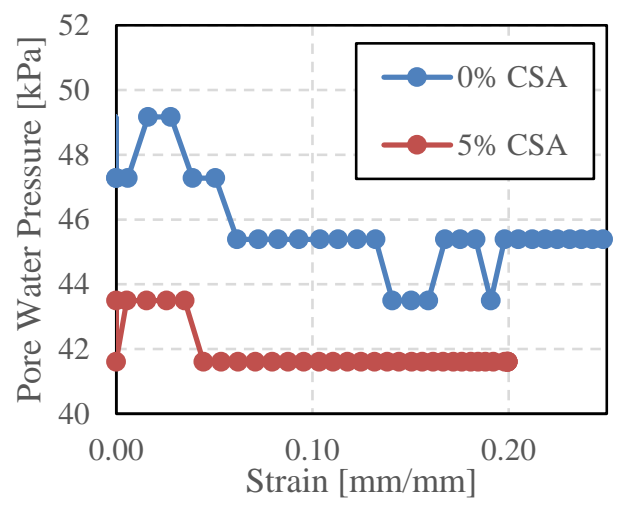

Fig. 4 Pore Water Pressure-Strain Curve at $50 \mathrm{kPa}$ Consolidating Pressure

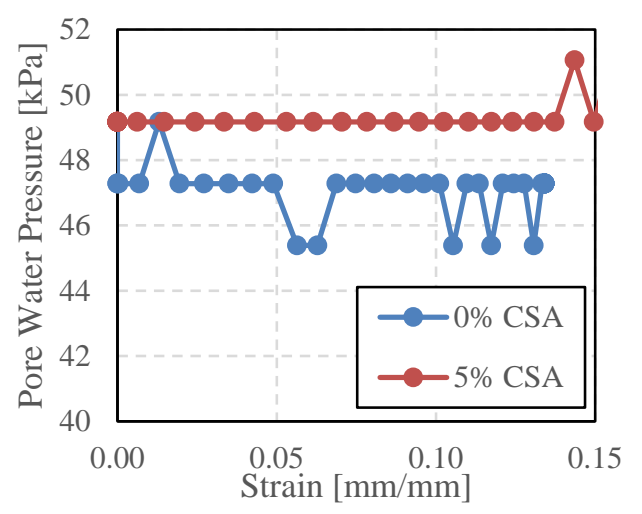

Fig. 5 Pore Water Pressure-Strain Curve at $100 \mathrm{kPa}$ Consolidating Pressure 


\subsection{Shear Strength Parameters}

The shear strength parameters are tabulated in Table 2. The effective friction angle was used to find the slope of the critical state line in the CamClay model. The $5 \%$ CSA caused the friction angle in the total stress condition to increase from $31.7595^{\circ}$ to $38.1076^{\circ}$. The five (5) percent CSA did not cause a significant increase in friction angle in the effective stress condition.

Table 2. Friction Angles

\begin{tabular}{ccc}
\hline CSA & $\phi$ & $\phi^{\prime}$ \\
\hline $0 \%$ & $31.7595^{\circ}$ & $38.2902^{\circ}$ \\
$5 \%$ & $38.1076^{\circ}$ & $38.2073^{\circ}$ \\
\hline
\end{tabular}

\subsection{Cam-Clay Model}

The Cam-Clay model in the q-p' space for the sample at $5 \%$ CSA and subjected to $25 \mathrm{kPa}$ consolidating pressure is presented in Fig. 6. The stress paths lie to the right of the critical state line. The same is also observed in all the other samples. This indicates that all samples are normally consolidated and lightly overconsolidated soils. Thus, the samples will compress and undergo strain hardening. For the sample at $5 \%$ CSA and subjected to $25 \mathrm{kPa}$ consolidating pressure, the equations for the yield surface and critical state line in the q-p' space are defined by Eq. 6 and Eq. 7, respectively.

$$
\frac{q}{1.558 p^{\prime}}+\ln \left(\frac{p^{\prime}}{122.619}\right)=0
$$

$q=1.588 p$
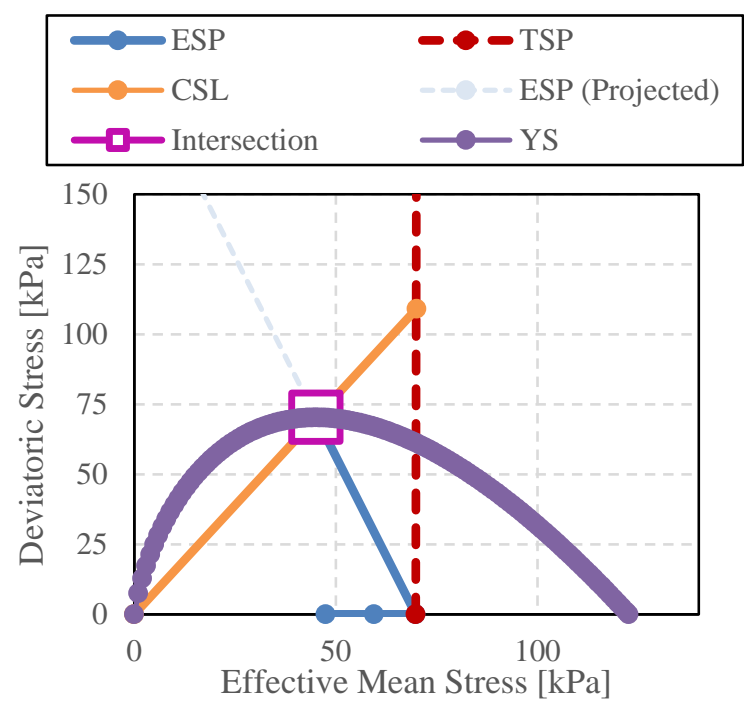

Fig. 6 Mohr's Circle and Failure Envelope at 5\% CSA and 25kPa Consolidating Pressure
The parameters required to construct the CamClay model are tabulated in Table 3. The samples without CSA have a critical state line slope value of 1.562, while the samples mixed with $5 \%$ CSA have a critical state line slope value of 1.558 . This is because the critical state line slope is computed from the effective friction angle

Table 3. Cam-Clay Model Parameters and Void Ratio After Consolidation Phase

\begin{tabular}{ccccc}
\hline Sample & $\mathrm{M}$ & $\Gamma$ & $\mathrm{e}_{\mathrm{c}}$ & $\lambda$ \\
\hline $\begin{array}{c}0 \% \mathrm{CSA} \\
25 \mathrm{kPa}\end{array}$ & 1.562 & 0.463 & 0.429 & 0.0108 \\
$0 \% \mathrm{CSA}$ & & & & \\
$50 \mathrm{kPa}$ & 1.562 & 0.416 & 0.365 & 0.0144 \\
$0 \% \mathrm{CSA}$ & & & & \\
$100 \mathrm{kPa}$ & 1.562 & 0.436 & 0.415 & 0.0052 \\
$5 \% \mathrm{CSA}$ & & & & \\
$25 \mathrm{kPa}$ & 1.558 & 0.441 & 0.390 & 0.0156 \\
$5 \% \mathrm{CSA}$ & & & & \\
$50 \mathrm{kPa}$ & 1.558 & 0.477 & 0.388 & 0.0256 \\
$5 \% \mathrm{CSA}$ & 1.558 & 0.472 & 0.402 & 0.0181 \\
$100 \mathrm{kPa}$ & & & & \\
\hline
\end{tabular}

The Cam-Clay model in the q-a-e space is a 3D model which shows the boundary surface. All combinations of deviatoric stress, effective mean stress, and void ratio within the boundary surface will not result in soil failure and are considered safe. The boundary surface shows that the yield surface decreases as the void ratio increases. Soil becomes more susceptible to failure at larger void ratios, or looser soil states. In other words, the soil's ability to exhibit elastic responses improves at lower void ratios or denser soil states. The Cam-Clay model in the q-p'-e space for the sample at $5 \%$ CSA and subjected to $25 \mathrm{kPa}$ consolidating pressure is presented in Fig. 7.

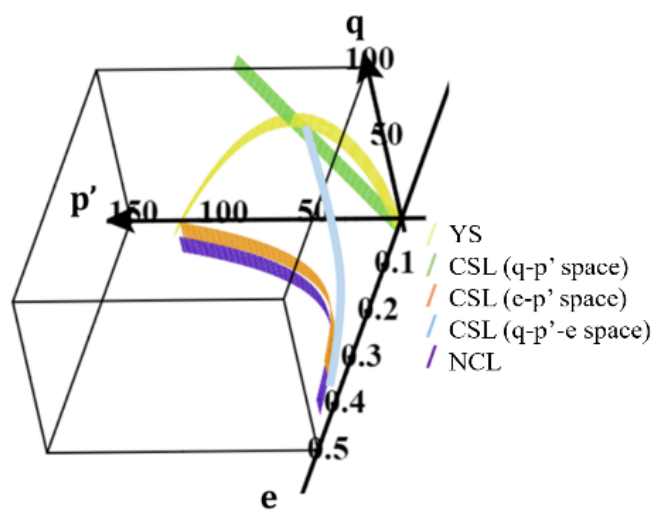

Fig. 7 3D Cam-Clay Model at 5\% CSA and 25kPa Consolidating Pressure 
For the same sample, the critical state line in the e-lnp' space and normal consolidation line are defined by Eq. 8 and Eq. 9, respectively.

$e=0.441+0.0156 \ln p^{\prime}$
$e=0.456+0.0156 \ln p^{\prime}$

The friction angle for dense sands ranges between $36^{\circ}$ and $41^{\circ}$. The samples in the study have a relative density of $70 \%$, indicating dense sand. The friction angles obtained fall within the range for dense sands, verifying that the samples are in the dense state [44]. Summarized in Table 4 is the pore water pressure buildup at failure for the samples.

Table 4. Pore Water Pressure Buildup at Failure

\begin{tabular}{|c|c|c|c|}
\hline $\begin{array}{l}\text { Consolidation } \\
\text { Pressure[kPa] }\end{array}$ & $\begin{array}{c}\Delta \mathrm{u}_{0 \% \mathrm{CSA}} \\
{[\mathrm{kPa}]}\end{array}$ & $\begin{array}{c}\Delta \mathrm{u}_{5 \% \mathrm{CSA}} \\
{[\mathrm{kPa}]}\end{array}$ & \%Decrease \\
\hline 25 & 51.890 & 57.460 & -10.73 \\
\hline 50 & 77.506 & 72.442 & 6.53 \\
\hline 100 & 113.746 & 107.429 & 5.55 \\
\hline
\end{tabular}

Five percent CSA decreased pore water pressure buildup by $6.53 \%$ and $5.55 \%$ for the samples subjected to consolidating pressures of $50 \mathrm{kPa}$ and $100 \mathrm{kPa}$, respectively. The decrease in pore water pressure buildup is attributed to the small particle size of CSA, which occupies the soil voids and reduces the amount of water that occupies the soil voids. However, an adverse effect was observed in the sample subjected to $25 \mathrm{kPa}$ consolidating pressure when mixed with $5 \%$ CSA. The sample exhibited a $10.73 \%$ increase in pore water pressure buildup. The low consolidating pressure negated the effect of CSA. Sufficient consolidating pressure is required for $5 \%$ CSA to decrease pore water pressure buildup.

The effect of CSA on the yield surface is analyzed by comparing the yield surfaces at $0 \%$ CSA and $5 \%$ CSA. Results are shown in Figs. 8 to 10.

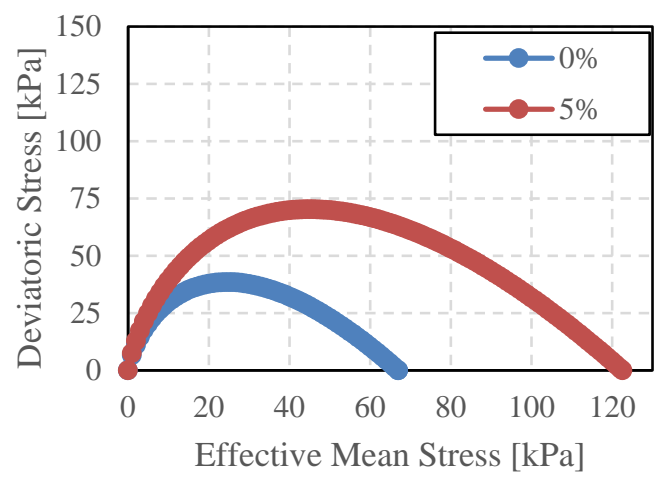

Fig. 8 Yield Surfaces at 25kPa Consolidating Pressure

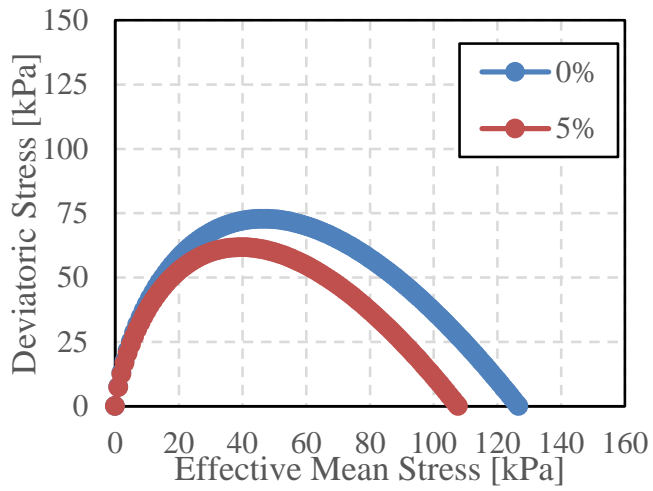

Fig. 9 Yield Surfaces at 50kPa Consolidating Pressure

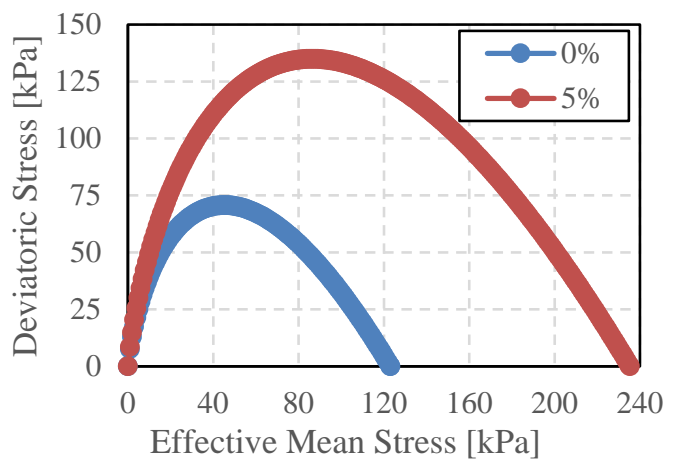

Fig. 10 Yield Surfaces at $100 \mathrm{kPa}$ Consolidating Pressure

Plastic deformations are unrecoverable and occur when stress states lie beyond the yield surface. Within the yield surface, soils exhibit elastic responses to deformations. An expanded yield surface indicates that soil is more able to respond elastically to heavier loads. In other words, soil deformations become much more recoverable. It can be seen in Fig. 8 and 10, for 5 \% CSA mixture with $25 \mathrm{kPa}$ and $100 \mathrm{kPa}$ consolidation pressure their yield surface expanded. However, for $50 \mathrm{kPa}$ consolidation pressure $5 \%$ CSA as shown in Fig. 10 it did not experience expansion. It was observed upon inspection of the sample after the experiment most of the CSA settled at the bottom. This was due to the lack of contact of CSA to the soil sample.

Summarized in Table 5 are the preconsolidation stresses, the current consolidating pressures ( $\left.\sigma_{3}\right)$, and the over consolidation ratios. $\mathrm{R}_{0}$ values less than or equal to 2 define normally consolidated and lightly overconsolidated soil. From the $\mathrm{R}_{\mathrm{o}}$ values obtained, all samples fall into the classification of normally consolidated and lightly overconsolidated soil. Normally consolidated soil is expected to have a stress-strain behavior that does not exhibit a linear elastic state. For this type of soil, strain hardening is more pronounced and it behaves as an elastoplastic 
material. A lightly overconsolidated soil is expected to exhibit a linear elastic state then followed by strain hardening. Also for this type of soil, it behaves as an elastoplastic material. To a considerable extent, the stress-strain curves of the samples, shown in Fig. 1 and Fig. 2, resemble the expected behavior of both a normally consolidated and lightly soil, respectively.

Table 5. Overconsolidation Ratios

\begin{tabular}{cccc}
\hline Sample & $\mathrm{p}_{0}{ }^{\prime}[\mathrm{kPa}]$ & $\sigma_{3}[\mathrm{kPa}]$ & $\mathrm{R}_{0}$ \\
\hline 0\%CSA 25kPa & 67.008 & 63.000 & 1.1 \\
0\%CSA 50kPa & 126.627 & 94.100 & 1.3 \\
$0 \%$ CSA 100kPa & 123.086 & 138.100 & 1.0 \\
$5 \%$ CSA 25kPa & 122.619 & 69.800 & 1.8 \\
$5 \%$ CSA 50kPa & 107.662 & 88.000 & 1.2 \\
$5 \%$ CSA 100kPa & 235.364 & 130.500 & 1.8 \\
\hline
\end{tabular}

\section{CONCLUSION}

No liquefaction occurred in all samples because the pore water pressure buildup for all samples was insufficient to induce liquefaction. The five (5) percent CSA resulted in decreased fluctuations in the pore water pressure-strain graphs. A reduction in pore water pressure generation was also observed from the graphs. Five percent CSA effectively expanded the yield surface, which makes the soil more able to respond elastically to heavier loads and recover from deformations. Five percent CSA reduced the pore water pressure buildup in the samples subjected to $50 \mathrm{kPa}$ and $100 \mathrm{kPa}$ consolidating pressure by $6.53 \%$ and $5.55 \%$, respectively. Therefore, five (5) percent CSA is effective in decreasing pore water pressure generation in sands at $70 \%$ relative density. To a considerable extent, the expected stress-strain behavior of soil is in agreement with the actual soil behavior of the samples. The Cam-Clay model validated the samples to be normally consolidated and lightly overconsolidated soil.

\section{REFERENCES}

[1] Retrieved from https://depts.washington.edu/liquefy/html/why /why1.html.

[2] Uy E. E. S., Noda T., Nakai K., and Dungca J. R., Monitoring the Triggering of Liquefaction Using Image Processing, International Journal of GEOMATE, Vol. 15, Issue 51, 2018, pp.180-187.

[3] Uy E. E. S., Noda T., Nakai K. and Dungca J. R., Non-Contact Estimation of Strain Parameter-Triggering Liquefaction, International Journal of GEOMATE, Vol. 16,
Issue 57, 2018, pp.82-88.

[4] Adajar M. A., Galupino J., Frianeza C., Faye Aguilon J., Sy J. B., and Tan P. A., Compressive Strength and Durability of Concrete with Coconut Shell Ash as Cement Replacement, International Journal of GEOMATE, Vol. 18, Issue 70, 2020, pp. 183190.

[5] Dungca J. R., Galupino J. G., Alday J. C., Barretto M. A. F., Bauzon M. K. G. and Tolentino, A. N., Hydraulic Conductivity Characteristics of Road Base Materials Blended with Fly Ash and Bottom Ash, International Journal of GEOMATE, Vol. 14, Issue 44, 2018, pp. 121-127.

[6] Elevado K. J. T., Galupino J. G., and Gallardo, R. S., Compressive Strength Optimization of Concrete Mixed with Waste Ceramics and Fly Ash, International Journal of GEOMATE, Vol. 16, Issue 53, 2019, pp. 135-140.

[7] Galupino J., Adajar M. A., Uy E. E., Koa N. C., Lao A. L., Lao R. N. and Tan, J. C. M., Performance Of Concrete Mixed With Fly Ash and Plastic When Exposed To Fire. International Journal of GEOMATE, Vol.19, Issue 74, 2020, pp. 44-51.

[8] Galupino J. G. and Dungca J. R., Permeability Characteristics of Soil-Fly Ash Mix, ARPN Journal of Engineering and Applied Sciences, Vol. 10, Issue 15, 2015, pp. 6440-6447.

[9] Adajar M. A., Aquino C. J., dela Cruz J. D., Martin C. P., and Urieta, D. K., Investigating The Effectiveness of Rice Husk Ash As Stabilizing Agent of Expansive Soil, International Journal of GEOMATE, Vol. 16, Issue 58, 2019, pp. 33-40.

[10] Dungca J. R. and Jao J. A., Strength and Permeability Characteristics of Road Base Materials Blended with Fly Ash and Bottom Ash, International Journal of GEOMATE, Vol. 12, Issue 31, 2017, pp. 9-15.

[11] Dungca J. R., Lao W. D., Lim M., Lu W. D., and Redelicia J. C. P. (2019). Radial flow permeameter: A Proposed Apparatus to Measure Horizontal Hydraulic Gradient of FlyAsh Based Geopolymer-Soil Mix, International Journal of GEOMATE, Vol. 16, Issue 58, 2019, pp. 218-223.

[12] Elevado K. T., Galupino J. G., and Gallardo, R. S., Compressive Strength Modelling of Concrete Mixed with Fly Ash and Waste Ceramics Using K-Nearest Neighbor Algorithm, International Journal of GEOMATE, Vol. 15, Issue 48, 2018, pp. 169174.

[13] Elevado K. T., Galupino J. G., and Gallardo, R. S., Artificial Neural Network (ANN) Modelling of Concrete Mixed with Waste Ceramic Tiles and Fly Ash, International 
Journal of GEOMATE, Vol. 15, Issue 51, 2018, pp. 154-159.

[14]Dungca J. R. and Galupino J. G., Artificial Neural Network Permeability Modeling of Soil Blended with Fly Ash, International Journal of GEOMATE, Vol. 12, Issue 31, 2017, pp. 76-83.

[15] Dungca J. R. and Galupino J. G., Modelling of Permeability Characteristics of Soil-Fly AshBentonite Cut-Off Wall Using Response Surface Method, International Journal of GEOMATE, Vol. 10, Issue 4, 2016, pp. 20182024.

[16] Ilies N., Farcas V., Gherman C., Chiorean V., and Popa D., Soils efficient improvement solutions with waste materials and binders. Journal of Environmental Protection and Ecology, Vol. 16, Issue 4, 2015, pp. 1397-1406.

[17] Uy E. E. S., Adajar M. A. Q., and Galupino J. G., Utilization of Philippine Gold Mine Tailings as A Material for Geopolymerization, International Journal of GEOMATE, Vol. 21, Issue 83, 2021, pp. 28-35.

[18] Adajar M. A. and Cutora M. D. L., The Effect of Void Ratio, Moisture Content and Vertical Pressure On the Hydrocompression Settlement of Copper Mine Tailing, International Journal of GEOMATE, Vol. 14, Issue 44, 2018, pp. 82 89.

[19] Adajar M. A., de Guzman E., Ho R., Palma C. and Sindico D. Utilization of Aggregate Quarry Waste in Construction Industry, International Journal of GEOMATE, Vol. 12, Issue 31, 2017, pp. 16-22.

[20] Adajar M. A. and Pabilona, W. N. K., (2018). Soil-Structure Interface Behavior of Cemented-Paste Backfill Material Mixed with Mining Waste, International Journal of GEOMATE, Vol. 14, Issue 44, 2018, pp. 102108.

[21] Adajar M. A. Q. and Zarco M. A. H., An Empirical Model for Predicting Hydraulic Conductivity of Mine Tailings, International Journal of GEOMATE, Vol. 7, Issue 2, 2014, pp. 1054-1061.

[22] Adajar M. A. Q. and Zarco M. A. H., Predicting the Stress-Strain Behavior of Mine Tailing Using Modified Hyperbolic Model, International Journal of GEOMATE, Vol. 10, Issue 3, 2016, pp. 1834-1841.

[23] Uy E. E. S., Adajar M. A. and Dungca J. R., Volume Change Behavior of Sea Water Exposed Coal Ash Using Hyperbolic Model. International Journal of GEOMATE, Vol. 16, Issue 58, 2019, pp. 97-103.

[24] Uy, E. E. S., and Dungca, J. R., A Comparative Settlement Prediction of Limestone Blended Materials Using Asaoka and Hyperbolic Method, International Journal of GEOMATE, Vol. 14, Issue 43, 2018, pp. 63-69.
[25] Uy E. E. S. and Dungca J. R, Hyperbolic Model Parameters of Philippine Coal Ash, International Journal of GEOMATE, Vol. 15, Issue 47, 2018, pp. 95-102.

[26] Dungca J. R. and Dychangco L. F. T., Strength Properties of Road Base Materials Blended with Waste Limestones, International Journal of GEOMATE, Vol. 11, Issue 3, 2016, pp. 2493-2498.

[27] Dungca J., Galupino J., Sy C. and Chiu A. S. F. (2018). Linear Optimization of Soil Mixes in The Design of Vertical Cut-Off Walls, International Journal of GEOMATE, Vol. 14, Issue 44, 2018, pp. 159-165.

[28] He J., Ivanov V. and Chu J., Mitigation of Liquefaction of Saturated Sand Using Biogas, Géotechnique, Vol. 63, Issue 4, 2013, pp. 267275.

[29] Ibrahim E., Diambra A., Wood D. M. and Russell A. R., Static Liquefaction of Fiber Reinforced Sand Under Monotonic Loading, Geotextiles and Geomembranes, Vol. 28, Issue 4, 2010, pp/ 374-385.

[30] Muhammad N., Namdar A. and Zakaria I., Liquefaction Mechanisms and Mitigation-A Review, Research Journal of Applied Sciences, Engineering and Technology, Vol. 5, Issue 2, 2012, pp. 574-578.

[31] Porcino D., Marciano V., and Granata R., Static and Dynamic Properties of A Lightly Cemented Silicate-Grouted Sand, Canadian Geotechnical Journal, Vol. 49, Issue 10, 2012, pp. 1117-1133.

[32] Sabbar A., Chegenizadeh A. and Nikraz H., Static Liquefaction of Very Loose Sand-SlagBentonite Mixtures, Soil, and Foundations, Vol. 57, Issue 3, 2017, pp. 341-356.

[33] Nakamichi M. and Sato, K., A Method of Suppressing Liquefaction Using A Solidification Material and Tension Stiffeners, in Proc. of the 18th International Conference on Soil Mechanics and Geotechnical Engineering, 2013, pp. 1547-1550.

[34]Liyanage C. and Pieris M., A PhysicoChemical Analysis of Coconut Shell Powder, International Symposium on Applied Chemistry, 2015, pp. 222-228.

[35] Gandia, Famero, and Sarno, Coconut Shell Ash as Stabilizer for Base Course, Undergraduate Thesis, 2014.Retrieved August 13, 2018, from https://thesis.dlsud.edu.ph/2766/1/CE0412014 .pdf.

[36] Jain, A., Liquefaction Potential In and Around Manila. 2016, Retrieved from http://www.airworldwide.com/Blog/Liquefaction-PotentialIn-and-Around-Manila/

[37]Budhu M., Chapter 11, Soil Mechanics and Foundations, $3^{\text {rd }}$ Edition, John Wiley \& Sons, Inc., 2010, pp. 324-361 
[38] Powrie W., Chapter 5, Soil Mechanics Concepts and Applications, $2^{\text {nd }}$ Edition, Taylor \& Francis, 2004, pp.

[39] Uy E. E. S. and Dungca J. R., Constitutive Modeling of Coal Ash Using Modified Cam Clay Model, International Journal of GEOMATE, Vol. 12, Issue 31, 2017, pp. 88-94.

[40] Uy E. E. S. and Adajar M. A., Assessment of Critical-State Shear Strength Properties of Copper Tailings, International Journal of GEOMATE, Vol. 12, Issue 32, 2017, pp. 12-18.

[41] Kumar N., and Kumar, D., Utilization of Coconut Shell in Different Forms in Concrete, International Journal for Scientific Research \& Development, Vol. 2, Issue 7, 2014, pp. 158-
160.

[42] Wadhwa A., Thamilarasu V. and Rajprasad J., An Experimental Investigation on Physical, Chemical and Mechanical Properties of Concrete Blocks Mixed Partially with Burnt Coconut Shell Powder. International Journal of Chemical Sciences, Vol. 14, Issue S1, 2016, pp. 353-358.

[43] Peck R., Hanson W. and Thornburn T. Chapter 4, Foundation Engineering Handbook. Wiley, London, 1974.

Copyright (C) Int. J. of GEOMATE All rights reserved, including making copies unless permission is obtained from the copyright proprietors. 